\title{
Impacts of Advertising and Sales Promotion on Brand Equity of Soft Drinks
}

\author{
LÂE ĐĂNG LĂNG \\ Master of Arts, University of Economics and Law \\ Email: danglangle@yahoo.com
}

\begin{abstract}
The paper aims to illuminate the relationship between advertising, promotions and brand equity. First of all, a preliminary research is conducted by means of group discussions and in-depth interviews to formulate a measurement scale. Then, to conduct the official research, 339 questionnaires are disseminated to respondents to collate data. The EFA, Cronbach's Alpha, and CFA are utilized to test the scale. Hypotheses are tested by the SEM. Analytical results indicate that the determinants of brand equity in the soft drinks industry comprise: brand awareness, perceived quality, brand associations and brand loyalty. Advertising positively affects components of the brand equity; promotions can enhance the perceived quality; the brand awareness boosts brand associations; and the perceived quality promotes the brand loyalty.
\end{abstract}

Keywords: brand equity, soft drinks, advertising, sales promotion, Vietnam 


\section{INTRODUCTION}

In the context of rapid globalization, brand name building can consolidate competitive edges of an enterprise (Aaker, 1996). In developed countries, this issue has been properly attended to and many strong brand names have been developed. Specifically, according to Interbrand, top-three leading brand names in the world in 2012 comprise Coca-Cola (US\$77.8 billion), Apple (US\$76.6 billion) and IBM (US\$75.5 billion).

In Vietnam, together with the penetration of multinationals like Rejoice, Tide, Sunsilk, Omo, Coca-Cola, and so on since the early 1990s, development of a strong brand name is really a matter of concern, especially after 2000. It is possible to exemplify some Vietnamese favorite brand names including Không Độ, Number One; Trung Nguyên, Vinamilk and so on. However, numerous brand names, especially those of fast-moving consumer goods (FMCG), have not been successfully built.

Moreover, in the FMCG market, soft drinks make up the largest share with the most dynamic and competitive business climate. Specifically, according to Datamonitor (2010), the value of soft drinks such as bottled drinking water, bottled coffee, bottled tea, fruit juice, carbonated beverages, tonics, or the like which have been sold in Vietnam reached US\$786.4 million in 2009 and was predicted to soar to US\$1,119.8 million in late 2014. Meanwhile, hot drinks such as coffee and tea which are served hot reached US\$708.4 million in 2009 and were expected to hit US\$853.4 million in 2014. Therefore, in the soft drinks market, albeit branding has been properly attended to, some enterprises such as Laser, TriO and X2 cannot make their own names.

Numerous theoretical and empirical studies indicate that in order to boost brand equity, it is necessary to beef up promotion which, if conducted effectively, can help increase brand equity in customers' mind (Yoo et al., 2000). Yet in Vietnam, it is not always true that application of promotional tools can develop a brand name or increase brand equity. Hence, opting for an appropriate promotional tool is crucial to build brand equity. Although there have been various studies concerning such issues such as Aaker (1991), Keller (1993), Yoo et al. (2000), and Ramos and Franco (2005), they are merely for developed countries with certain durable consumer goods while those for a developing country like Vietnam are quite rare. Therefore, this paper aims to test the relationship between brand equity of soft drinks and the two common promotional 
tools (i.e. advertising and sales promotion) which are often utilized by Vietnamese soft drinks manufacturers.

\section{REVIEW OF LITERATURES, RESEARCH MODEL, AND HYPOTHESES}

\section{a. Literature Review:}

Brand name may be a name, a phrase, a sign, a symbol, an icon, or a combination of these factors given to a type of product or group of products by the company that produces or sells them so that people will recognize and distinguish them from rival's products or services (AMA). Furthermore, some people believe that brand name is the set of attributes which can provide target customers with value as per their requirement (Davis, 2002).

In the field of marketing, development of brand name is its focus, which must be associated with other promotional tools to enhance brand equity. However, brand equity is produced by various components according to different viewpoints. For example, as Aaker (1991) states, brand equity is crucial to create distinctive features and boost competitive edges and is often measured by four main factors, that is, brand loyalty, brand awareness, perceived quality and brand associations. In the meantime, Keller (1993) contends that brand equity is customers' knowledge of the brand name and is measured by brand awareness and brand impression. In Vietnam, Nguyễn Đình Thọ and Nguyễn Thị Mai Trang (2011), in their research on the shampoos in HCMC in 2002, introduce three components of brand equity of consumer goods in Vietnam namely brand awareness, perceived quality, brand desire. Additionally, according to Kotler (1994), promotion is a part of marketing mix in addition to product, price and sales; and comprises five principal tools: advertising, public relations, sales promotion, personal selling and direct marketing. In short, advertising and sales promotion are main tools of promotion or marketing communication.

\section{b. Research Model and Hypotheses:}

In this paper, the model of components of brand equity developed by Aaker (1991, 1996) is employed due to its popularity. Moreover, advertising and sales promotion, the two primary promotional tools, are used to test their relationship with brand equity of soft drinks. Although unable to fully represent all promotional activities, these variables are commonly utilized to measure the building of brands of soft drinks. Thus, the paper tests impacts of advertising and sales promotion on brand equity of soft 
drinks in Vietnam through brand awareness, brand associations, perceived quality and brand loyalty. The research model is:

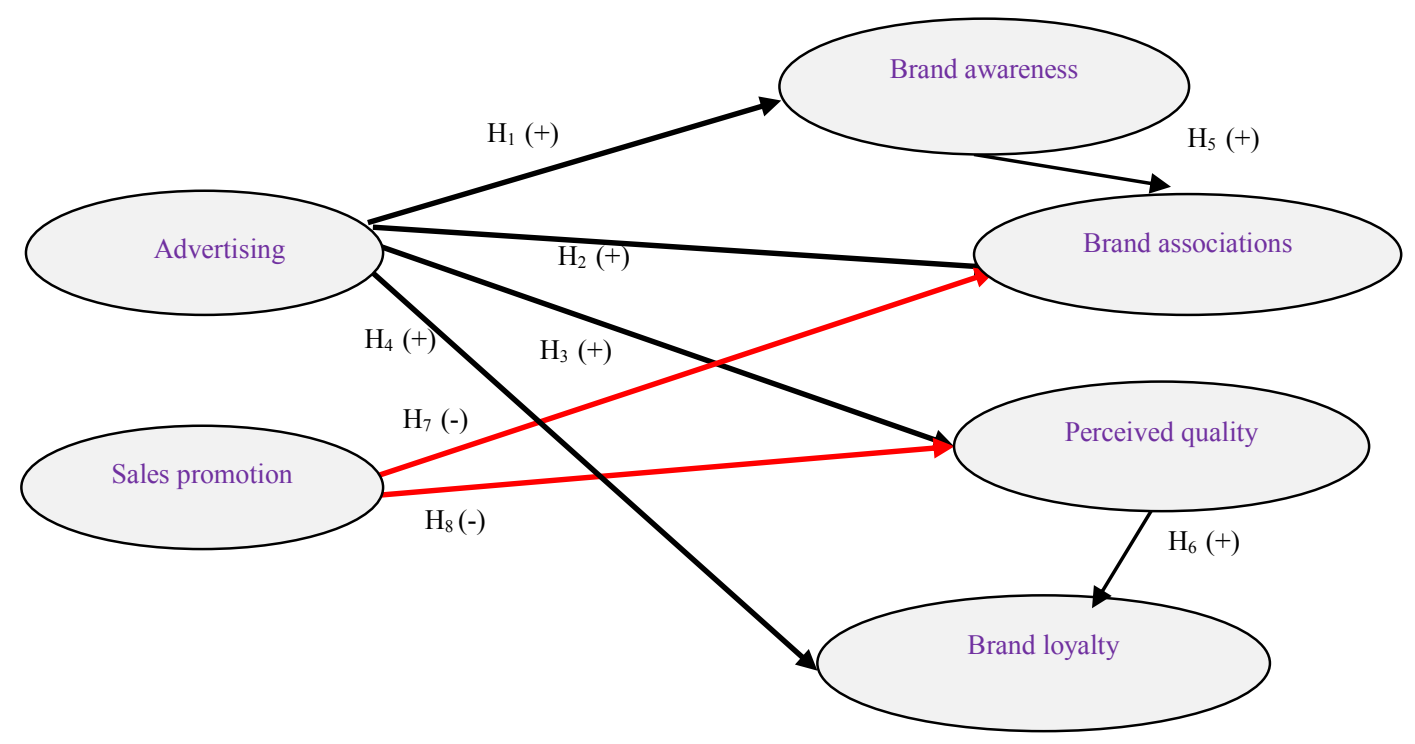

Figure 1: Research model

Various researches on advertising have indicated that advertising could generate brand equity. Specifically, the amount of investments in advertising can positively affect brand equity and its components such as brand awareness, brand associations and perceived quality (Yoo et al., 2000; Ramos and Franco, 2005; Amaretta and Hendriana, 2011). In addition, advertising also has positive impacts on the brand loyalty because it can boost brand associations and attitude toward a brand (Yoo et al., 2000). Simultaneously a greater awareness of brand can increase brand associations, and a higher perceived quality can improve brand loyalty. Accordingly, hypotheses can be stated as follows:

H1: The high investment in advertising has positive effects on the brand awareness $(+)$.

H2: The high investment in advertising has positive effects on the brand associations $(+)$.

H3: The high investment in advertising has positive effects on the perceived quality $(+)$. 
H4: The high investment in advertising has positive effects on the brand loyalty $(+)$.

H5: The acute brand awareness has positive effects on brand associations $(+)$.

H6: The high perceived quality has positive effects on brand loyalty $(+)$.

Additionally, according to Aaker (1991), albeit sales promotion can increase the sales within the short term, it cannot have significant effects on the development of brand equity and even can produce opposite effects. Regular promotion can lead to impression of an unstable quality of goods in public perception (Yoo et al., 2000). The fact that consumers cannot predict the price precisely due to the disparity between the expected price and the quoted one may sharply impinge on the perceived quality. Furthermore, sales promotion does not last long enough to be able to generate a better awareness of brand. Seemingly, sales promotion is not related to brand loyalty even though it increases the shift to a new brand for the time being (Yoo et al., 2000; Ramos and Franco, 2005). Once a promotion is over and economic benefits no longer exist, customers will lose their interest in a certain brand. Therefore, the hypotheses 7 and 8 are stated as follows:

H7: The high frequency of sales promotion will decrease brand associations (-).

H8: The high frequency of sales promotion will decrease perceived quality of brand $(-)$.

\section{RESEARCH METHOD AND MEASUREMENT SCALE}

\section{a. Methodology:}

Both qualitative and quantitative methods are utilized in the research. In the preliminary research, based on existing measurement scales developed by previous academic researchers, the research scale was adjusted via discussion in groups of eight in April 2012. In-depth interviews were then conducted on the basis of ready-made questionnaires $(n=100)$ to test the scale. Furthermore, scales are also tested by Cronbach's Alpha, exploratory factor analysis (EFA), principal component analysis (PCA) and Varimax rotation. The preliminary research was conducted in May 2012.

Given results from the preliminary research, the author design the questionnaire for the actual research which was conducted by in-depth interviews with 339 respondents on June 2012. Its measurement scales were tested by EFA using principal axis factoring (PAF) with Promax oblique rotation, Cronbach's Alpha and confirmatory factor analysis (CFA) (Amos 20). 
Eventually, the structural equation model (SEM), a comprehensive statistical model which combines multivariable regression and factor analysis and is frequently used to test impacts of an independent quantitative variables on a dependent quantitative one, is employed to test the research model and hypotheses. Using PAF with Promax oblique rotation reflects a more precise data structure than using PCA with Varimax rotation (GErbing and Anderson, 1988). Hence, it is better to employ PAF to evaluate the research scale. PCA with Varimax rotation is merely used to extract more variances from variables. The research subjects are consumers of soft drinks aging from 18 to 25 . Majority of them are students of universities in HCMC and are randomly selected. In the questionnaire, the Seven-point Likert scale is employed with one as "absolutely disagree" and seven as "absolutely agree". Date are filtered and then processed by SPSS 20.

\section{b. Measurement Scale:}

This paper utilizes existing measurement scales of previous academic research and then adjusts them to fit the case of Vietnam. As was stated above, the research employs six constructs, that is: investments in advertising (with seven observed variables and signed as $\mathrm{AD}$ ); sales promotion (three variables, DL); brand awareness (six variables, $\mathrm{BA}$ ); brand associations (six variables, AA); perceived quality (five variables, $\mathrm{PQ}$ ); brand loyalty (fives variables, $\mathrm{BL}$ ); and overall brand equity (four variables, $\mathrm{OBE}$ ).

\section{FINDINGS AND DISCUSSION}

\section{a. Findings:}

The measurement scales of advertising and sales promotion are tested by EFA using PAF with Promax oblique rotation on the condition that the factor loading coefficients of variables must be larger than 0.5 (Hair et al., 2006) and the difference between loadings must be larger than 0.3 (Jabnoun and Al-Tamimi, 2003). The results are presented in Table 1. 


\section{Table 1: EFA Results Using PAF with Promax for Variables of Advertising and} Sales Promotion

\begin{tabular}{|c|c|c|c|}
\hline \multirow[b]{2}{*}{ Codes } & \multicolumn{2}{|c|}{ Extracted factors } & \multirow[b]{2}{*}{ Interpretation of variables } \\
\hline & $\begin{array}{l}\text { Advertising } \\
\text { (1) }\end{array}$ & $\begin{array}{l}\text { Sales promotion } \\
\text { (2) }\end{array}$ & \\
\hline AD2 & 0.872 & & I am very fond of ads for product $X$. \\
\hline AD3 & 0.857 & & I highly appreciate ads for X. \\
\hline $\mathrm{AD} 1$ & 0.824 & & I think ads for $\mathrm{X}$ are good. \\
\hline AD6 & 0.506 & & Advertising campaigns for $\mathrm{X}$ is very regular. \\
\hline DL2 & & 0.933 & $\begin{array}{l}\text { Price promotion for } \mathrm{X} \text { is conducted with too high } \\
\text { frequency. }\end{array}$ \\
\hline DL3 & & 0.792 & Price promotion for $\mathrm{X}$ is overemphasized. \\
\hline DL1 & & 0.755 & $\mathrm{X}$ is regularly discounted. \\
\hline
\end{tabular}

With $\mathrm{KMO}=0.764>0.5$, the factor analysis is appropriate; and the Barlett test with Sig. $=0.000<0.5$ is statistically significant, and thus observed variables are overall correlated (Trọng and Ngọc, 2008). Given Eigenvalue $=2.057<1$ and the variance equaling $65.144 \%>50 \%$, the two factors are extracted as follows:

- Factor 1 includes items AD2, AD3, AD1 and AD6 which are the components of the variable "advertising".

- Factor 2 comprises items DL2, DL3 and DL1 which are the components of the variable "sales promotion"

As the Cronbach's Alpha coefficient indicates, the reliability of extracted factors is larger than 0.6 and the item-total correlation coefficient larger than 0.3; and thus they are acceptable (Nunnally and Burnstein, 1994). Unitarity, convergent validity and discriminant validity of scales are tested by CFA. CFA results, after adjusted on the basis of relationships having the modification indices (MI) larger than 4, show that the comparative fit index (CFI), the Tucker-Lewis index (TLI), and the goodness of fit index (GFI) are larger than 0.9, Chi-square/df equaling $2.7(<3)$ and the root mean square error of approximation (RMSEA) equaling $0.71(<0.8)$; and thus they are appropriate to market data (Nguyễn Đình Thọ and Nguyễn Thị Mai Trang, 2008), and variables attain their unitarity (Steenkamp \& Van Trijp, 1991). Standardized regression 
weights of scales, when tested, are larger than 0.5 at the statistical significance level smaller than 0.05 (Table 2), so scales achieve convergent validity (Gerbing and Anderson, 1988). Additionally, the correlation coefficients of scales are smaller than $0.9(r=0.149)$, discriminant validity is assured (Hair et al., 2006).

Table 2: CFA Weights for Advertising and Sales Promotion

\begin{tabular}{cccccccc}
\hline \multirow{2}{*}{ Codes } & & & \multicolumn{3}{c}{ Non-standardized } & \multicolumn{2}{c}{ Standardized } \\
\cline { 3 - 7 } & & & Estimate & S.E. & C.R. & P & Estimate \\
\hline AD6 & $<---$ & Advertising & 1.000 & & & & 0.521 \\
AD3 & $<---$ & Advertising & 1.441 & 0.147 & 9.820 & $* * *$ & 0.855 \\
AD2 & $<---$ & Advertising & 1.582 & 0.160 & 9.914 & $* * *$ & 0.882 \\
AD1 & $<---$ & Advertising & 10.364 & 0.143 & 9.566 & $* * *$ & 0.802 \\
DL3 & $<---$ & Sales promotion & 1.000 & & & & 0.774 \\
DL2 & $<---$ & Sales promotion & 1.059 & 0.067 & 15.863 & $* * *$ & 0.937 \\
DL1 & $<---$ & Sales promotion & 0.945 & 0.064 & 14.845 & $* * *$ & 0.772 \\
\hline
\end{tabular}

\section{b. Testing Measurement Scales of Components of Brand Equity:}

Conducting EFA for the scales of components of brand equity using PAF with Promax rotation generates results in Table 3. With $\mathrm{KMO}=0.842>0.5$ and the Bartlett Sig. $=0.000<0.05$, Eigenvalue $=1.084>1$ and the variance $=63.29 \%>50 \%$, they are acceptable (Gerbing and Anderson, 1988), and four extracted factors are:

Factor 1 comprises items BL1, BL2, BL3, and BL4; and is named "brand loyalty."

Factor 2 comprises items AA1, BA4, BA5 and BA6; and is named "brand associations."

Factor 3 comprises items PQ1, PQ2, PQ4 and PQ5; and is named "perceived quality."

Factor 4 comprises items BA1, BA2 and BA3; and is named "brand awareness." 
Table 3: Factor Extraction Matrix for Components of Brand Equity

\begin{tabular}{|c|c|c|c|c|c|}
\hline \multirow[b]{2}{*}{ Codes } & \multicolumn{4}{|c|}{ Extracted factors } & \multirow[b]{2}{*}{ Interpretation of variables } \\
\hline & $\begin{array}{c}\text { Brand } \\
\text { loyalty } \\
\text { (1) }\end{array}$ & $\begin{array}{c}\text { Brand } \\
\text { associations } \\
(2)^{[*]}\end{array}$ & $\begin{array}{l}\text { Perceived } \\
\text { quality } \\
\text { (3) }\end{array}$ & $\begin{array}{c}\text { Brand } \\
\text { awareness } \\
\text { (4) }\end{array}$ & \\
\hline BL3 & 0.908 & & & & $\begin{array}{l}\text { I will not buy any products of the same } \\
\text { type if } X \text { is available on shelves. }\end{array}$ \\
\hline BL4 & 0.760 & & & & $\begin{array}{l}\text { I just seek to buy X but not anything of } \\
\text { the same type. }\end{array}$ \\
\hline BL2 & 0.754 & & & & $\mathrm{X}$ is my first choice. \\
\hline BL1 & 0.634 & & & & I think I am loyal to $\mathrm{X}$. \\
\hline BA6 & & 0.837 & & & $\begin{array}{l}\text { Comprehensively, it is easy for me to } \\
\text { visualize } X \text {. }\end{array}$ \\
\hline BA5 & & 0.811 & & & $\begin{array}{l}\text { I can quickly recall and recognize X's } \\
\text { logo. }\end{array}$ \\
\hline BA4 & & 0.749 & & & $\begin{array}{l}\text { X's attributes come to my mind } \\
\text { quickly. }\end{array}$ \\
\hline AA1 & & 0.633 & & & $\begin{array}{l}\text { X's distinctive features come to my } \\
\text { mind quickly. }\end{array}$ \\
\hline PQ4 & & & 0.843 & & $\mathrm{X}$ is reliable. \\
\hline PQ1 & & & 0.796 & & $\mathrm{X}$ 's quality is high. \\
\hline PQ5 & & & 0.705 & & $\mathrm{X}$ 's quality is high for sure. \\
\hline PQ2 & & & 0.689 & & $\begin{array}{l}\text { There is possibility that X's quality is } \\
\text { exorbitant. }\end{array}$ \\
\hline BA2 & & & & 0.896 & $\begin{array}{l}\text { I can easily realize } X \text { among other soft } \\
\text { drinks. }\end{array}$ \\
\hline BA3 & & & & 0.798 & $\begin{array}{l}\text { I can easily distinguish } \mathrm{X} \text { from other } \\
\text { soft drinks. }\end{array}$ \\
\hline BA1 & & & & 0.688 & I have knowledge of X's brand name. \\
\hline
\end{tabular}


NB: [*] This construct is a little different from the initial one due to the fact that brand awareness and brand associations are construed identically. It is also the reason why some researchers in the world group these two constructs together.

The reliability test indicates that the Cronbach's Alpha of extracted factors is larger than 0.6 and the item-total correlation larger than 0.3; and they they are plausible (Nunnally and Burnstein, 1994). Next, the author conducts CFA to test the unitarity, convergent validity, and discriminant validity of scales. Accordingly, CFA results after adjusted produce CFI, TLI and GFI larger than 0.9, Chi-square/df equaling $2.738(<3)$ and RMSEA equaling $0.72(<0.8)$; and thus they are congruent with market data, and the set of observed variables is considered to be unidirectional (Steenkamp and Van Trijp, 1991).

Due to the fact that the regression weights of scales are larger than 0.5 at the statistical signicance of 0.05 at most (Table 4), measurement scales attain the convergent validity (Gerbing and Anderson, 1988). Additionally, the correlation coefficients are different from zero $(\mathrm{r}<0.9)$, the scale achieves discriminant validity (Hair et al., 2006).

Table 4: CFA Weights for Components of Brand Equity

\begin{tabular}{cccccccc}
\hline \multirow{2}{*}{ Codes } & & & \multicolumn{3}{c}{ Unstandardized } & \multicolumn{2}{c}{ Standardized } \\
\cline { 3 - 7 } & & & Estimate & S.E. & C.R. & P & Estimate \\
\hline BL4 & $<---$ & Brand loyalty & 1.000 & & & & .577 \\
BL3 & $<---$ & Brand loyalty & 1.242 & 0.088 & 14.158 & $* * *$ & 0.681 \\
BL2 & $<---$ & Brand loyalty & 1.356 & 0.131 & 10.327 & $* * *$ & 0.826 \\
BL1 & $<---$ & Brand loyalty & 1.372 & 0.133 & 10.312 & $* * *$ & 0.822 \\
AA1 & $<---$ & Brand associations & 1.000 & & & & 0.701 \\
BA6 & $<---$ & Brand associations & 1.157 & 0.087 & 13.315 & $* * *$ & 0.813 \\
BA5 & $<---$ & Brand associations & 1.104 & 0.086 & 12.797 & $* * *$ & 0.775 \\
BA4 & $<---$ & Brand associations & 1.056 & 0.080 & 13.214 & $* * *$ & 0.805 \\
PQ5 & $<---$ & Perceived quality & 1.000 & & & & 0.755 \\
PQ4 & $<---$ & Perceived quality & 0.979 & 0.073 & 13.379 & $* * *$ & 0.762
\end{tabular}




\begin{tabular}{cccccccc} 
PQ2 & $<---$ & Perceived quality & 0.951 & 0.069 & 13.736 & $* * *$ & 0.761 \\
PQ1 & $<---$ & Perceived quality & 1.044 & 0.075 & 13.988 & $* * *$ & 0.774 \\
BA3 & $<---$ & Brand awareness & 1.000 & & & & 0.884 \\
BA2 & $<---$ & Brand awareness & 1.043 & 0.054 & 19.270 & $* * *$ & 0.880 \\
BA1 & $<---$ & Brand awareness & 0.849 & 0.059 & 14.339 & $* * *$ & 0.695 \\
\hline
\end{tabular}

\section{c. Hypotheses Test:}

The SEM is used to test the model and hypotheses (AMOS 20). The initial model is not congruent with the market data due to Chi-square/df $=3.409>3, \mathrm{CFI}=0.886$ and $\mathrm{TLI}=0.868<0.9 ;$ RMSEA $=0.084>0.08$. After adjusting the model by means of adjusting relationships that have the MI larger than four, the new model is considered to be congruent with the market data (Figure 2) due to Chi-square/df $=2.8<3$; CFI = $0.915>0.9 ;$ TLI $=0.901>0.9 ;$ RMSEA $=0.073<0.08$.

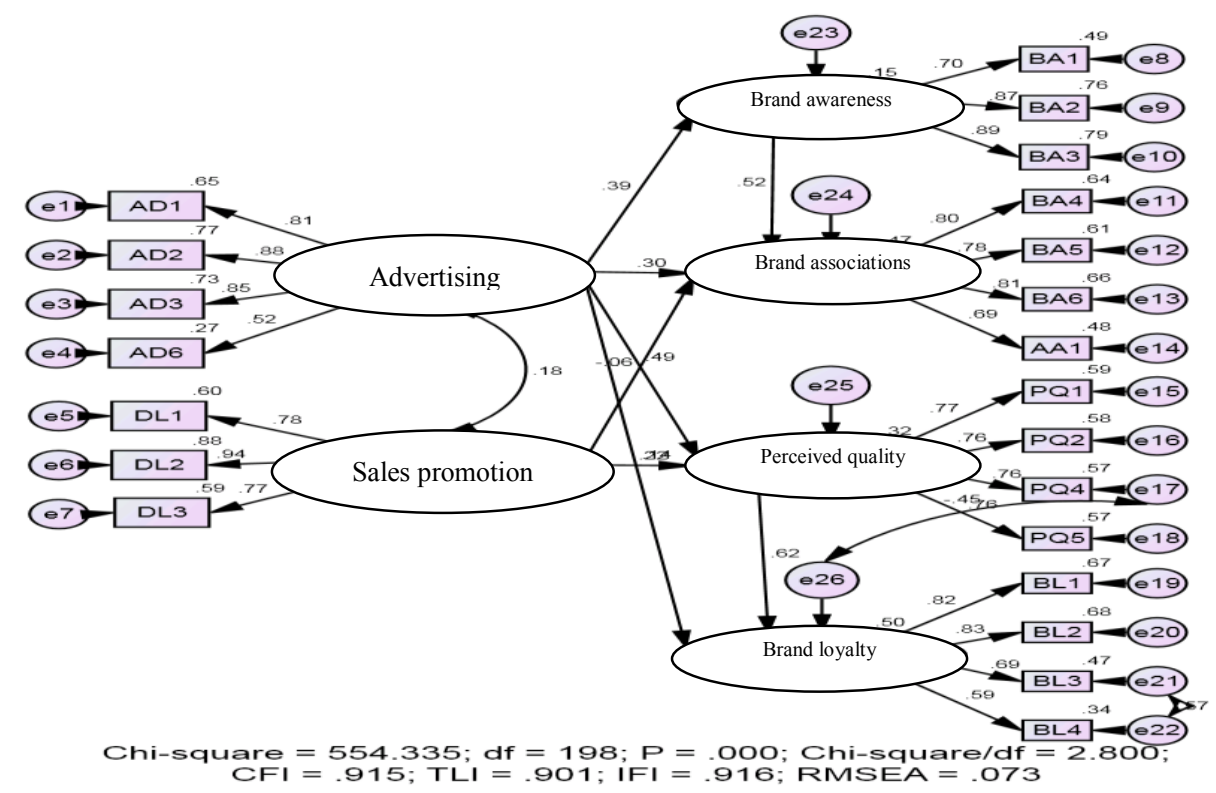

Figure 2: SEM testing results

The testing results on the weights of relationships between scales are presented in Table 5. Such weights do not change much or distort the nature of correlation of scales in the initial model. Accordingly, it is possible to arrive at conclusions presented in Table 5. 
Table 5: SEM Testing Results

\begin{tabular}{ccccccccc}
\hline & & & \multicolumn{3}{c}{ Unstandardized } & \multicolumn{2}{c}{ Standardized } \\
\cline { 3 - 7 } & & & Estimate & S.E. & C.R. & P & Estimate \\
\hline Perceived quality & $<---$ & Sales promotion & 0.200 & 0.050 & 3.979 & $* * *$ & 0.221 \\
Brand awareness & $<---$ & Advertising & 0.551 & 0.102 & 5.427 & $* * *$ & 0.385 \\
Perceived quality & $<---$ & Advertising & 0.700 & 0.107 & 6.554 & $* * *$ & 0.487 \\
& & & & & & & \\
Brand associations & $<---$ & Advertising & 0.376 & 0.080 & 4.707 & $* * *$ & 0.296 \\
Brand loyalty & & & & & & & \\
Brand associations & $<----$ & Advertising & 0.227 & 0.105 & 2.150 & 0.032 & 0.140 \\
Brand associations & $<---$ & Bdvertising & -0.045 & 0.040 & -1.120 & 0.263 & -0.056 \\
Brand loyalty & $<---$ & Perceived quality & 0.700 & 0.086 & 8.172 & $* * *$ & 0.622 \\
\hline
\end{tabular}

- H1 is accepted $(\mathrm{p}<0.05)$, and thus high investment in advertising has positive effects on the brand awareness $(+)$.

- H2 is accepted $(\mathrm{p}<0.05)$, and thus high investment in advertising has positive effects on the brand associations $(+)$.

- H3 is accepted $(\mathrm{p}<0.05)$, and thus high investment in advertising has positive effects on the perceived quality $(+)$.

- H4 is accepted ( $\mathrm{p}=0.032<0.05)$, and thus high investment in advertising has positive effects on the brand loyalty $(+)$.

Apparently, advertising has positive effects on components of brand equity; in other words, it can enhance brand equity. Also, the standardized regression weights indicate advertising has the greatest impacts on perceived quality ( 0.487$)$, followed by brand awareness (0.385), brand associations (0.296), and brand loyalty $(0.140)$.

Table 5 also shows that $\mathrm{H} 5$ is acceptable $(\mathrm{p}<0.05)$; and thus better awareness of brand will improve brand associations $(0.520)$. H6 is also accepted $(\mathrm{p}<0.05)$ and thus the high perceived quality will boost brand loyalty (0.622). Furthermore, sales 
promotion has positive impacts on perceived quality with the standardized impact weight of 0.221 and the statistical significance being smaller than 0.05 ; and thus $\mathrm{H} 8$ is rejected. The relationship between sales promotion and brand associations is not statistically significant due to $p=0.263>0.05$; and thus it is impossible to draw any conclusion in accordance with $\mathrm{H} 7$.

Moreover, the $\mathrm{R}^{2}$ coefficient shows that advertising can explain $14.8 \%$ of changes in brand awareness and $49.8 \%$ of changes in brand loyalty; and simultaneously advertising and sales promotion can explain $46.9 \%$ of changes in brand associations and $32.4 \%$ of changes in perceived quality.

\section{DISCUSSION}

\section{a. Theoretical Contributions:}

The research proves that brand equity of soft drinks made in Vietnam is measured by brand awareness, brand associations, perceived quality and brand loyalty; and that advertising has positive impacts on components of brand equity. Such findings confirm previous results by Aaker (1991), Yoo et al. (2000), Ramos and Franco (2005), etc. concerning components of brand equity and impacts of advertising on them both in the field of durable consumer goods and in soft drinks industry of a newly-emerging market like Vietnam.

In addition, the research also extends some significant additions, that is: (1) better awareness of brand can enhance brand associations, and (2) higher perceived quality can increase brand loyalty. Such findings illuminate the close relationship between components of brand equity and explain why well-known brand names are often considered to be more reliable than others. Once a brand is acutely aware, the brand loyalty will definitely be high.

Additionally, the research also discovers disparities to previous findings but specific to soft-drink manufacturers in Vietnam; that is, sales promotion can enhance the perceived quality of a brand. There are two reasons for this difference: (1) the paper focuses on soft drinks of FMCG industry which is extremely different from durable good industry; and (2) characteristics of Vietnamese market are different from those of the US or Spanish ones.

\section{b. Implications:}


The research's findings are significant to beverage manufacturers in general and soft-drink manufacturers in particular. In essence, building a brand name is to develop brand equity, so it is advised that business administrators and marketers identify components of brand equity in order to develop more effective strategies and solutions.

Furthermore, determination of influential factors is also significant to development of brand equity. The paper implies that advertising can improve components of brand equity, that sales promotion can enhance the perceived quality, that brand awareness boosts brand associations, and that perceived quality promotes brand loyalty. Such findings can be used to orient the development of marketing communication in order to build a strong brand name and reduce costs.

Moreover, soft drinks can represent FMCG sector, thus related manufacturers can apply the findings to branding. Last but not least, measurement scales of advertising, sales promotion and components of brand equity, which have been tested, are a significant source of data for market researchers in Vietnam to design questionnaires. Yet, marketing administrators should be careful when employing business theories in general and marketing ones in particular due to the fact that different markets and different products possess different characteristics.

\section{c. Limitations and Orientations for Further Research:}

Like many other studies, limitations are inevitable. Firstly, the data is just collated in HCMC. Secondly, the study only investigates impacts of advertising and sales promotion, yet there are many different modes of promotion employed by various companies in practice. Eventually, every mode of advertising or promotion is often associated with various tools, and the industry of soft drinks is also split into subindustries of carbonated beverage, fruit juice, etc. Hence, in the upcoming years, it is necessary to test impacts of other types of promotion such as public relations or TV sponsorship, etc. on components of brand equity. At the same time, the data should be collated nationwide from different sub-industries of soft drinks

\section{References}

Aaker, D.A. (1991), Managing Brand Equity, Free Press, New York. Aaker, D.A. (1996), Building Strong Brands, Free Press, New York. 
Amaretta, M. \& E. Hendriana (2011), "The Effect of Marketing Communications and Price Promotion to Brand Equity", Proceedings of the 2nd International Research Symposium in Service Management in Yogyakarta, Indonesia.

Datamonitor (2010), Hot Drinks \& Soft Drinks Market in Vietnam to 2014, Ref. Code: DBCM7358/ DBCM8049.

Gerbing, D.W. \& J.C. Anderson (1988), “An Update Paradigm for Scale Development Incorporating Unidimensionality and Its Assessments", Journal of Marketing Research, Vol.25(2), pp.186-192.

Hair, J.F.; B. Black; B. Babin; R.E. Anderson \& R.L. Tatham (2005), Multivariate Data Analysis, 6th Ed., Prentice Hall, New Jersey.

Hoàng Trọng \& Chu Nguyễn Mộng Ngọc (2008), Phân tích dũ liệu nghiên cứu với SPSS, Hồng Đức Publisher, HCMC.

Keller, K.L. (1993), "Conceptualizing, Measuring and Managing Customer-Based Brand Equity", Journal of Marketing, Vol.1, pp.1-22.

Keller, K.L. (1998), Strategic Brand Management, Prentice Hall, New Jersey.

Kotler, P. \& K.L. Keller (2009), Marketing Management, Prentice Hall, New Jersey.

Kotler, P. (1994), Marketing Management, Prentice Hall, New Jersey.

Nguyễn Đình Thọ \& Nguyễn Thị Mai Trang (2011), Nghiên cứu khoa học Marketing: Úng dụng mô hình cấu trúc tuyến tính SEM, Lao động Publisher, HCMC.

Nguyễn Đình Thọ (2011), Phuoong pháp nghiên cưu khoa học trong kinh doanh: Thiết kế và thưc hiện, Lao động - Xã hội Publisher, HCMC.

Villarejo-Ramos, A.F \& M.J. Sánchez-Franco (2005), "The Impact of Marketing Communication and Price Promotion on Brand Equity", Journal of Brand Management, Henry Stewart Publications, Vol.12(6), pp.431-444.

Yoo, B.; N. Donthu \& S. Lee (2000), “An Examination of Selected Marketing Mix Elements and Brand Equity”, Journal of the Academy of Marketing Science, Vol.28(2), pp.195-211. 